\title{
CHARITABLE WORK OF THE CHURCH IN THE POLISH LANDS IN THE XIX CENTURY AND ITS IMPACT ON EDUCATION
}

\author{
LESZEK AFTYKA, PIOTR MAZUR
}

\begin{abstract}
The Catholic Church in the Polish lands in the XIX century has had numerous charity works. The charitable activities were seen as the task of God's commandment of love. The purpose of this activity was to support poor people in the form of satisfying basic material needs and achieving adequate personal development. The article discusses the most important forms of assistance provided by religious orders, as well as clerical and lay organizations. The author draws attention to the charity's impact on education and the formation of humanistic values in society. Many priests set up organisations that had such names as: "Star", "Aurora", "Fatherland", "Rock". Their main objective was to raise up education standards and stimulate patriotism and solidarity among young people. Therefore, cooperation between educational institutions, families, nongovernmental organizations, volunteer movements, charitable foundations for the expansion of active charitable activities, and the creation of a humanistic society is required. Nowadays it is extremely important to revive philanthropy and altruism in every country. Currently, there are foundations, organizations aimed at carrying out charitable activities and attracting to the charity all who wish to serve the cause of raising Christian morality, culture, education, art, support of the poor. Thus, this is important to promote it in the educational field as well. After all, many young people are ready to help financially or spiritually those who need it; they seek to invest time, money and talent into a rapidly growing charity. Here we see an important role of the Catholic Church, which influences the development of the spirituality of the individual.
\end{abstract}

Keywords: charity, social work, Catholic Church, education.

\section{INTRODUCTION}

The development of the industry at the turn of the XVIII and XIX centuries, and what is inextricably linked to the mass migration from the countryside to the cities, resulted in the emergence of new social problems. The workers of large industrial plants became a new category of those in need of support either due to the loss of employment and source of income, or due to poor working conditions lost their health and consequently also became unemployed, deprived of their livelihoods. The old and unfit for work also increased the number of seeking help [1, p. 45; 3, p.18].

Escalation of social problems in the XIX century was accompanied by the emergence of numerous organizations and charitable institutions. The progress of knowledge enabled at the same time to better identify causes and to find increasingly effective countermeasures. In the XIX century, charitable activity in industrialized countries is developing strongly [3, p.18]. 


\section{ANALYSIS AND DisCUSSION}

The encyclical of Pope Leo XIII Rerum Novarum (1891) became the stimulus for the development of charitable activity. It has had a huge impact on the creation of new charities, associations and care facilities. Their activities brought invaluable help to poor, unhappy, children, young people, workers, and people in need of moral and material assistance [6, p. 31].

All those who were involved in the works of mercy can be divided into three groups:

a) the funders of charitable institutions (orphanages, alms-houses, etc.), in the vast majority, were bishops, priests and noble family representatives (most often ladies of aristocracy);

b) people working directly among the poor and children in the field of care and education - the overwhelming majority were religious and nuns;

c) organizers who, with the help of selected collaborators, conducted caring and educational activities - founders of new religious congregations [6, p. 28].

The Scottish religious minister Thomas Chalmers is considered to be the father of modern social work. In 1822, he carried out an experiment in his parish, which consisted in the suspension of the Rights of the Poor. The parish was divided into various districts for which deacons were appointed. The task of each deacon was to make discernment on the needs, investigate individual cases and grant assistance. At the same time, Chalmers pointed to the need for savings, diligence and mutual help.

Among the Catholic organizations, the importance of the Society of Saint Vincent de Paul should be particularly emphasized. They were formed in Paris on 1833 at the initiative of Frederick Ozanam. The first members were mainly students of the Sorbonne [5, p. 59-75]. Originally, their activity was limited to supporting poor families by assigning vouchers that were implemented in designated stores. Over time, their activities have been expanded to support new forms of assistance: running cheap eateries and catering, caring for apprentices, labourers, moral education and teaching activities [3, p.19].

At the beginning of the 19th century, the Congregation of the Sacred Hearts of Jesus and Mary undertook pastoral work among the neglected youth and who sought to enable them to acquire appropriate professional qualifications. In the mid-nineteenth century, John Bosco started a similar initiative and is still continued by the Salesian Society and Salesian nuns [4, p. 1386].

In the XIX century, many societies of charity were founded on Polish lands: in Vilnius (1807 on the initiative of Bishop Jan Nepomucen Korwin-Kossakowski and Prof. Józef Franek); in Warsaw (1814 on the initiative of Zofia from Czartoryski Zamoyska), which founded the so-called penny savings bank; in Kraków (1816); Vilnius Society for the Poor; Association of Catholic Charities in Lviv (1895). Similar charities and organizations were established in Płock (1882), Sosnowiec (1900), in Przemyśl (1910), in Lublin (1815) and the Warsaw Christian Society for Women's Protection (1903), Society for the Care of Sick Workers in Poznań (1901), Society Care for the Blind in Warsaw (1911) and the association "Drop of milk" in Krakow (1907) [6, p. 31; 7, p. 67-70].

There were also numerous foundations for caring for orphans, including in Poznań (founded in 1848 by Archbishop Leon Przyłuski), Wolsztyn (1849), Gostyń (founded in 1849 by Edmund Bojanowski), Wschowa (1851), Jastrow (1859) and Tuczno (1864) [4, p. 1388].

Numerous foundations for caring for the poorest have also been established. The Society of Saint Vincent de Paul was transplanted to Poland (the first female in 1843 under the name of the Society of Merciful Ladies in Lwów and the first male 1850 in Poznań) [5, p. 61]. On the initiative of Archbishop Przyłuski, in 1855, the Society of the Mercy of the Blessed Virgin Mary was founded in Poznan. The Society of Saint Vincent de Paul organizations were established in various parts of Poland (in Greater Poland, Warmia, Lesser Poland, Silesia, and Pomerania). Special support was given by bishops, among others Archbishop Edward Likowski and Archbishop Józef Bilczewski [6, p. 27-28].

These organisations' work focused on helping poor youth. Bishop Ignacy Łobos emphasized that The Society has "an impact on the poor and gifted schoolchildren. It is not an exaggeration, a wellknown sentence, that very many geniuses, who are able to become the fame of the nation, perish miserably in oblivion among the poorer strata of society due to lack of resources for proper education. 
Well, this is also to be resolved by the Christian mercy of The Society of Saint Vincent de Paul, who learned about the poor and talented students, helps them to stay in schools. Finally, the Society extends its protection to the poor, and again in the best way. Having learned about which is the family remaining in poverty, they appoint one member from the group as the guardian of this family. The duty of such a guardian is to visit their poor personally and provide them with support, which is not a financial donation, which could be abused, but always ready donation in the form of the most necessary food, such as bread, groats, flour, and in case of illness also meat and milk as well as in ready-made clothing or a firewood, as well as in repaying the rent for the owner of the house itself. This support shall be served, already as ordinary weekly donations, already as extraordinary donations in certain circumstances, e.g. on Christmas or Easter [...]. The most important thing in all this activity of the Society of Saint Vincent de Paul is primarily a personal visit to the poor. It affects the giver and receiver of support in the good way. To fulfil good deeds at home, at your campfire, is indeed very easy, but also a very small merit; the poor shall not be treated in this way. Friends are visited personally, and only we are sending the intruders what we owe them that they would give us peace. Visiting the poor is a test stone of a truly merciful heart. Only by pulling away from our riches, visiting a pauper, breathing the same air as he is, thus becoming a member of his family for a moment, we can prove him that we truly love him, that we consider him a brother" [2].

Rev. Jan Siemiec created workshops for the poorest young people in Warsaw. Also, in Warsaw, Fr. Zygmunt Chełmicki founded the kitchen for the poor in 1881 and the Society of Almshouses and Shelters. Rev. Zygmunt Gorazdowski founded the Society for Providence in Lviv, a house of work and a plant for terminally ill and for foundlings. In 1894, rev. Ignacy Kłopotowski organized a workshop in Lublin for young people with cheap eatery and shelters [4, p. 1388; 7, p. 93-93].

Charitable activities on a large scale were led by religious nun congregations (Daughters of Charity of Saint Vincent de Paul, Felician Sisters, Sisters of Saint Elizabeth, Congregation of the sisters Servants of the Blessed Virgin Mary Immaculate Conception, Sisters of St. Joseph, Society of the Sacred Heart), helping the poorest and most needy. In particular, Fr. Honorat Koźmiński stands out and the congregations founded by him without the religious outfit (so-called secret society) [4, p. 1388]. The care taken by Zofia Truszkowska over poor children in Warsaw resulted in the creation of a new religious order - the Felician Sisters (1855). The main task of the sisters was to work among children and the rural population. Felician Sisters worked in Podlasie region in Poland and among Polish immigrants in the United States [6, p. 29].

The activities of Adam Chmielowski (Brother Albert), who devoted his life to poor and homeless, deserve special recognition. With them in mind, he created in Cracow Almshouse for homeless and women's shelter. His congregations: Albertine Brothers (1883) and Albertine Sisters (1891) continued his work [6, p. 30].

In the educational work with youth, the most important role was fulfilled by Fr. Bronisław Markiewicz, who noticed the necessity of care for neglected young people. For the care of orphans and vulnerable adolescents, he founded the Congregation of Saint Michael the Archangel (1892) and Nuns of Saint Michael the Archangel (1897). On his initiative, educational institutions and a craft school were established at Miejsce Piastowe [4, p. 1388].

Working with artisanal youth and craftspeople took different forms. Fr. Kazimierz Siemaszko (1847-1904) founded a shelter and a house of voluntary work in Cracow (also serving as a school for abandoned boys). The facility had its own holiday home in Czermna near Cracow [6, p. 30].

The Jesuit Fr. Mieczysław Kuznowicz founded the union of Industrial and Craft Youth (1907) in Kraków. The plant built by him, the working methods used in it, became a role model for this type of institutions throughout the country [6, p. 30].

Many priests devoted themselves to working with craftsmen. It was a supportive and caring character. They set up for them organizations that had names such as: "Star", "Aurora", "Fatherland", "Rock". Their main objective was to raise up education standards and stimulate patriotism and solidarity among young people [6, p. 30]. 
In the XIX century, the implementation of the commandment of charity was included in organizational forms. Numerous organizations of lay and clerical Catholics were founded in many countries, whose goal was charitable activity. However, with time it turned out that these initiatives require coordination and a certain unification. In this way, they wanted to ensure the best use of the potential of goodwill in the charitable activity of the Church in the country, in the diocese and parish [3, p.19].

The result of such efforts was a far-reaching improvement of social activities of institutions, created and conducted by people, guided by the Christian system of values [6, p. 30]. In France, on the initiative of L. Lefebvre, the central office in Paris was established - Office Centrale des Institutions Charitables (1870). In Germany, L. Werthmann founded Deutsche Caritas-Verband (1897) in Freiburg im Breisgau, where a study was conducted for the education of charitable workers and the Caritas magazine was published. In 1900, a charity Action Centre for Austria was established in Vienna - Zentralstelle für Freiwillige Wohltätigkeit [3, p.19].

At the turn of the 19th and 20th centuries, initiatives aimed at coordinating charitable activities were undertaken in the Polish lands. Association of Catholic Charity Societies and Unions was established in Lviv (1895). In 1907 in Poznań, priest Piotr Wawrzyniak and priest Stanisław Adamski founded the Polish-Catholic Association of Charities. In 1915 of the initiative of Bishop Adam S. Sapieha was created in Cracow Bishops Committee for the affected War (KBK) colloquially called Princely-Bishop's Committee [3, p. 380; 6, p. 32].

\section{CONCLUSIONS}

The activity of the Catholic Church in the Polish lands in the XIX century was directed towards a multidirectional charitable ministry, which was seen as tasks and activities arising from God's commandment of love and adequate to the needs of people suffering from material or spiritual poverty. The purpose of this activity was to provide poor people with the assistance necessary to meet basic material needs and to achieve adequate personal development.

Today it is extremely important to revive philanthropy and altruism in every country. Currently, there are foundations, organizations aimed at carrying out charitable activities and attracting to the charity all who wish to serve the cause of raising Christian morality, culture, education, art, support of the poor. Thus, this is important to promote it in the educational field as well. After all, many young people are ready to help financially or spiritually those who need it; they seek to invest time, money and talent into a rapidly growing charity. Here we see an important role of the Catholic Church, which influences the development of the spirituality of the individual.

\section{REFERENCES}

[1] Banaszak M. Historia Kościoła katolickiego, vol. 3. Akademia Teologii Katolickiej, Warszawa, 1991. (in Polish)

[2] Currenda. Pismo obwieszczające diecezji tarnowskiej. IX z 1890. (in Polish)

[3] Kamiński T. Praca socjalna i charytatywna. UKSW, Warszawa, 2004. (in Polish)

[4] Łukaszyk R., Woronowski F. Dobroczynne duszpasterstwo. W: Łukaszyk R., Bieńkowski L., Gryglewicz F. (Red.) Encyklopedia katolicka, 3. TN KUL, Lublin, 1989, 1385-1389. (in Polish)

[5] Myszor J. Konferencje św. Wincentego á Paulo - charytatywne stowarzyszenie katolików świeckich w Polsce; powstanie, rozwój i likwidacja (1850-1950). W: Skorowski H., Koral J. (Red.) Materiały sesji naukowej "Caritas - zawód czy powołanie?", Warszawa, 8-9 października, 1996, Societas, Warszawa, 1996, 59-75. (in Polish) 
[6] Pawlik S. Postuga charytatywna Kościoła w uchwałach polskich synodów po Soborze watykańskim II. Studium prawno-historyczne. Papieski Wydział Teologiczny, Wrocław, 2006. (in Polish)

[7] Styk J. Dzieło miłosierdzia chrześcijańskiego w diecezji lubelskiej w XIX i XX wieku. W: Mieczkowski A. (Red.) Dzieła miłosierdzia chrześcijańskiego w Polsce $i$ w archidiecezji lubelskiej. Bractwo Miłosierdzia im. św. Brata Alberta, Lublin, 1997, 89-111. (in Polish)

Address: Leszek Aftyka, Catholic University in Ružomberok, 1A, Hrabovská cesta, Ružomberok, 03401 , Slovakia;

Piotr Mazur, The State School of Higher Education in Chelm, 54, Pocztowa Str., Chełm, 22-100, Poland.

E-mail: aftyleks@gmail.com; pmazur@pwsz.chelm.pl

Received: 15.01.2020; revised: 26.02.2020.

Афтика Лешек, Мазур Піотр. Благодійна робота Церкви на польських землях у XIX столітті та їі вплив на освіту. Журнал Прикарпатського університету імені Василя Стефаника, 7 (1) (2020), 129-133.

У статті досліджено вплив католицької церква на польських землях у XIX столітті на розвиток благочинності. Благодійна діяльність розглядається автором як одне із завдань Божої заповіді любові. Зазначено, що метою цієї діяльності була підтримка бідних дюдей у вигдяді задоволення основних матеріальних потреб та досягнення адекватного особистісного розвитку. У статті представдено найважливіші форми допомоги, надані релігійними орденами, а також церковно-мирянськими організаціями. Автор звертає увагу на вплив благодійництва на освіту та формування гуманістичних ціннісних орієнтацій у суспільстві. Багато священиків створиди організації, які мади такі назви, як: "Зірка", "Аврора", “Вітчизна", “Скеля", основною метою яких було підвищення стандартів освіти, стимулювання розвитку патріотизму та содідарності серед молоді. Для цього необхідна співпраця освітніх закладів, сім'ї, громадських організацій, волонтерських рухів, благодійних фондів для поширення активної благодійної діяльності, створення гуманістичного суспільства. 3'ясовано, що причетних до милосердя осіб умовно подіяяють на такі групи: а) фундатори благодійних установ (сиротинців, милостинь тощо), серед яких головним чином буди єпископи, священики та представники знатних родин (найчастіше дружини аристократіі); б) люди, які працюють безпосередньо серед малозабезпечених осіб, дітей у сфері опіки та освіти, серед яких здебільшого монахині, представники релігіі, а також соціальні працівники; в) організатори, дідери, котрі 3 допомогою відібраних співробітників проводили просвітницькі заходи щодо виявлення мидосердя (зазвичай це - засновники нових релігійних конгрегацій).

Ключові слова: благодійність, соціальна робота, католицька церква, освіта. 